\title{
Constitutional and Legal Support of State-Owned Property Management in the Republic of Kazakhstan
}

\author{
Alfiya Raisovna Vorivodina \\ Kazakhstan Institute of Innovation and Telecommunication Systems \\ Republic of Kazakhstan, West Kazakhstan Region, City of Uralsk, Mametova Street, 81
}

\author{
Doi:10.5901/mjss.2015.v6n5s3p188
}

\section{Abstract}

\begin{abstract}
In work the mechanism of constitutional legal support of management of state-owned property is defined; research of formation and the main tendencies of legislative regulation of state-owned property as object of management is provided; constitutional and legal characteristics of the phenomenon of state-owned property, and also essence and value of asset management of the state are considered; system nature of management of the state-owned property consisting of two basic elements - activity of the state bodies and corporate structures managing property of the state locates. The analysis of the constitutional legal basis of the mechanism of administration in the field of implementation of the right of state-owned property is provided. Results of research can find application in law-enforcement practice, at implementation of scientific researches on problems of management of state-owned property. The factors defining relevance of this work, so its timeliness and the demand are: the cardinal changes of the management system state-owned property which happened in recent years; availability of essential gaps in implementation of control and supervising functions in the field of the arranging impact on activities for management of state-owned property; the low performance of administration of management process in this sphere; insufficient legal support of existence and implementation of the public relations as which object state-owned property acts; limitation of theoreticmethodological and conceptual justification of essence, the contents, management structure state-owned property and in particular with use of opportunities of corporate subjects; dissociation of levels and the industries of public administration.
\end{abstract}

Keywords: State-owned property, state assets, constitution.

\section{Introduction}

In the economic sphere both the state and private equity at the same time works. According to the Constitution of RK in Kazakhstan are recognized and are similarly protected the state-owned and private property. The property obliges, use of it shall serve the public benefit at the same time. The present stabilization stage of development of the country, creation of post-industrial economy demands the statement of the state as the full owner of the capital. In particular this direction of the state policy shows the demand in the conditions of the world economic crisis when one of the conventional methods of mitigation of its effects is active participation of the state in management of economy.

The main part of state-owned property in modern conditions is made by the state share blocks and the state shares in property of economic partnerships. Review of the role of the state as regulator and as the full participant of the market relations is defined by need of increase of effective management of state-owned property, further development of the national companies, national holdings, and other new corporate government institutions performing the state administration in the field of property management of the state.

Ensuring activities for management of state-owned property can be performed in the unique form - by means of creation and implementation of the sufficient, effective legal base based on which the economic relations in this sphere are under construction. As that legal basis, the system of the precepts of law established and authorized by the state providing this area of economic activity acts. The constitution has the highest legal force and direct action in all territory of the Republic of Kazakhstan. The law in force in the Republic of Kazakhstan are regulations of the Constitution, laws corresponding to it, other regulatory legal acts, the international contractual and other commitments of the Republic, and normative resolutions of the Constitutional Council and Supreme Court of the Republic. It is possible to note that in Kazakhstan there is the uniform constitutional and legal space where the Constitution of RK carries out the role of the backbone, fundamental regulatory legal act for all system of law on the basis of which the system of the sources of law providing implementation of the managerial relations in the field of implementation of the right of state-owned property forms.

The new direction of legal and organizational support of economic reforms is implementation of law-making 
process on settlement of activity of corporate structures (specially created companies) exercising control of state-owned property.

Such is the incomplete circle of the questions causing relevance and need of studying of the perspective of constitutional legal support of management of state-owned property. The above formed the basis for determination of the direction of research, its character, specifics, structure and methods of research.

The theoretical importance of work is caused by carrying out complex the systematization existing and development of new scientific development in the field of constitutional legal support of management of state-owned property, the status of the subjects managing property of the state. Work can form the basis for further scientific researches of constitutional and legal aspects of management of state-owned property.

\section{Overview of Literature}

The considered subject was investigated by specialists fragmentary. Results of the analysis of single questions of legal support of management of state-owned property, some problems of the state administration in the field of management of state-owned property are reflected in scientific literature.

Scientists were always interested in problems of management of state-owned property. To development of theoretical bases of property management, entrepreneurship including the state entrepreneurship works of foreign scientists are devoted: Smith, (1993); Seius (2008), Weber (2010); Caldwell (2003); Ebenstein (2003) \& Friedman (2007). Modern questions of the state entrepreneurship are considered Druker (2012); Baumol (2013); Kotler (2009); Sachs (2005), Fischer (2002) and others. Foreign researchers, as a rule, did not allocate the category "state ownership" in the separate analytical plane and mainly talked about functions of the state in modern economy, need of the state intervention in economy, borders and forms of such intervention.

Very actual objects of scientific researches of the Soviet period were regulatory issues of the property right to state-owned property. These problems are considered in works: loffe (1975); Pokrovsky (2000) \& Shershenevich (1995), etc.

Collapse of the USSR, demonopolization of institute of state-owned property, development of the private property institution in the conditions of market economy caused cardinal changes in the relations in the field of implementation of the right of state-owned property. Such change needed qualitatively new scientific judgment and justification, new legislative regulation of the legal relationship arising in process of management of state-owned property was necessary.

The researches of scientists on the constitutional right, which are available today, are devoted to studying of the general questions of the constitutional legal basis of state-owned property and separate aspects of management by it. Among them - theses of such Russian scientists as Doroshenko (2005); Zhilinsky (2005); Kurilov (2003); Lepyokhin (2003); Mazayev (2005) \& Razmyslovich (2003).

E.V. Nesterova's works provide Works of the Kazakhstan researchers, E.A. Buribayeva (20) where civil aspect of management is investigated by state-owned property. The question of methods and the principles of management of state-owned property is object of close attention of the leading representatives of civil science: Basina (2003) \& Suleymenova (2008), etc.

At the same time, questions of constitutional legal support of management of state-owned property in the Republic of Kazakhstan were not object of independent complex scientific research. Statement of the problem in the offered foreshortening of its studying through the constitutional legal mechanisms providing implementation of the managerial relations as which object state-owned property in general acts with the dominant position of the state assets, was not the subject of scientific researches of the constitutional and legal orientation.

Thus, the analysis of the available scientific development testifies to low-study of the subject of work and need of the new view on the considered problem.

\section{Methods and Materials}

Regulatory legal base of work was the legislation of the Republic of Kazakhstan and foreign countries. In the analysis of the legislation on single questions of the status of the subjects, managing state-owned property of the Republic of Kazakhstan the corresponding comparison with provisions of the legislation of some foreign countries was carried out states of the European Union, China, countries of the Eurasian economic union. As the practical basis of research practice of application by the subjects managing state-owned property, and the bodies performing administration in this sphere, the current legislation in the field of property management, information of bodies of statistics, data on financial performance of management of state-owned property, and judgments was applied. 
The methodological basis of research was made dialectic, logic-legal, social and legal, comparative and legal, system and structural, etc. methods when studying tendencies of development of the doctrine about management of state-owned property and its legislative fixing the historical and legal method was applied.

In the course of writing of research doctrinal provisions of philosophy, the general legal theory, the constitutional right, the administrative right, civil law were applied. Statistical data on activity of the state bodies and corporate structures managing state-owned property are investigated.

\section{Results}

Novelty of research consists that for the first time in the Republic of Kazakhstan the complex of problematic issues of determination of mechanisms of constitutional legal support of management of state-owned property is considered, legal status of subjects of management is developed, the theoretical judgment of methods of the state administration in the field of activities for management of state-owned property is carried out. Scientific novelty of research is defined by the following results received in work:

1. The characteristics making the constitutional and legal design of the concept "state ownership" are established, the ratio of the concept "state assets", with adjacent legal categories is analyzed, and special value of assets of the state in system of objects of the right of state-owned property is stated.

2. Key parameters of the constitutional legal mechanism of ensuring management of state-owned property are determined; the main tendencies of evolution of legislative providing property management of the state are revealed.

3. The maintenance of the constitutional power of the Government of RK on the organization of management of state-owned property is opened.

4. The system of governing bodies of property of the state is defined, tendencies of its modern functioning are established.

5. The role of local public authorities in the controlling mechanism is considered by state-owned property.

6. The corporate management system is revealed by state-owned property, her subjects are defined, their forms of business of activity are investigated, the principles of their activities for management of state-owned property are generalized.

7. Bodies of administration of activities for management of state-owned property are systematized; the constitutional bases of their interaction are defined.

8. Problems of legal support of effective management of the state assets are shown; recommendations for lawmaking in this sphere are made.

\section{Decision}

Key parameters of constitutional legal support of management of state-owned property in the Republic are the purposes, valuable orientations and the fundamental principles of activity of the state of Kazakhstan based on the sovereign the right of the people of Kazakhstan. The social orientation of functioning of state-owned property and its focus on service for the benefit of all people is also among key parameters of constitutional legal support of management of state-owned property in the Republic of Kazakhstan. Control of state-owned property shall be exercised within and limits, and from height of the specified constitutional legal requirements and level of regulation of all activity of public authorities of the Republic.

For the sphere of management of state-owned property, constitutional legal support can be determined by the contents as creation of sufficient and effective system of the regulatory legal acts having unity and interrelation in which the leader directing the role belongs to the Constitution of the Republic of Kazakhstan.

Modern financial and economic conditions staticize questions of legal support of management of state-owned property that is caused by essential change of its role and value for national economic system. The public sector of economy is necessary for maintenance of functions of the state, and for further effective development of society in general.

Control of state-owned property is exercised system of the state bodies belonging to the executive branch of the power, and this work owing to special importance of object of management for national economy of the President of Kazakhstan is headed. Direct control of state-owned property is exercised at the present stage the Government of RK, thus the tendency to authority delegation of the central executive body to National welfare fund of "Samruk-Kazyn", the industry ministries by means of use of institute of the state representatives in governing bodies of legal entities with the 
state participation amplifies.

The corporate structures managing state-owned property incorporate powers of the state as owner as business executive, and also separate powers on public administration, thus, often have the form of business of private legal entity. Such symbiosis of functions of managing company is possible only in the sphere of economy strategically important for the state and society. Control over property is provided with participation of the Government of the Republic of Kazakhstan (or local executive bodies, National Bank of the Republic of Kazakhstan) in the created legal entities.

Some basic characteristics of subjects of corporate management are allocated with state-owned property. First, forming of the state assets assigned to the manager - legal entity with participation of the state, is carried out by means of transfer to the account of payment of its authorized capital of the legal entities which are earlier created or created in the future. Secondly, activity of these companies accountable to the state on behalf of authorized bodies. Thirdly, implementation of different transactions with property is carried out, at least with the report before state body, or from its consent, or permission. Fourthly, state bodies trace the solvency of activity of the subjects managing the state assets.

Modern administration of management of state-owned property is performed systemically, with use of mechanisms of state and imperious control and management. In system of state bodies special structures were created by the main activity which the arranging impact on the public relations in the field of implementation of the right of state-owned property is. At the same time legal support of the relations on management of state-owned property in general and the state assets in particular significantly lags behind practice of their implementation.

The carried-out analysis allowed to allocate the main problems having system character, being the serious slowing-down factors in achievement of the goal - increases of efficiency of legal support of activity of the companies managing the state assets:

- discrepancy of the current state of the legislation regulating activity of the companies managing the state assets, to the level of necessary and sufficient legal support of the main directions of the proclaimed and implementable state policy in this sphere;

- availability of the significant amount of shortcomings of legal regulation of the managerial relations, which object the state assets act, lack of efficient mechanisms of the state control of activity of the companies, the existing opportunities for corruption manifestation are the consequence of that;

- lack of due systematization and standardization of the legislation in the field of activity of managing companies that does not allow to define the general principles of their activity, the basis of legal status, the right and duty, the general rules of behavior in the managerial relations.

\section{Conclusion}

The constitutional principle of economic development for the benefit of all people defines active participation of the state in the economic relations, in implementation of its economic function. On the one hand, the state makes the regulating impact on all economic relations, being the participant of the vertical public relations, on the other hand, the state itself acts as the organizer of public sector of economy, the participant of the horizontal private-law relations, as equal among equal in the economic sphere.

In the course of research, we consistently track the tendency of development of legal support of the management of state-owned property in the Republic of Kazakhstan directed on formations of our state as the effective owner.

The developments of world economic system of change of crisis character happening in the present stage force the governments to review practically all countries of the world the state policy in the field of the economic relations, and as one of the major and significant directions participation of the state in the economic relations, implementation of administrative methods of management of all economy, and not just its public sector becomes more increasing.

The current state of economy and new global challenges demand acceptance from the states of more active participation in economic processes, strengthening of public administration by economy, in some cases with use of nonstandard methods. For the purpose of control over the allocated public funds for maintenance of financial wellbeing of the strategic companies of the state even more often go on the way of their acquisition to property, by means of acquisition of shares in authorized capital, share blocks. Public administration by economy becomes the major stabilizing by regulation of the economic relations. Current situation assumes not so much strengthening of the role of the state in economy, and how many increase of efficiency of public administration by economy at the optimum combination of the controlling influence of the state and democratic principles of economic activity.

The constitution of the Republic of Kazakhstan, fixing bases of institute of property, not only creates opportunity, but also obliges the state to perform regulation of market economy and to adjust its laws according to interests of society, the person, and the state. 
The constitutional and legal design of state-owned property as general category, allowed allocating state-owned property as object of the right of state-owned property, in turn the state assets we defined as the type of state-owned property and one of types of objects of the right of state-owned property. Special attention and interest in questions of effective management of the state assets it is caused by the variety of reasons. First, among all objects of state-owned property in modern conditions the state assets make powerful part, by means of management with which the state has possibility of the arranging impact on other objects of state ownership - real estate, industrial complexes, financial institutions. Now the most part of state-owned property is controlled multistage - through activities for management of the state assets which consist in participation in governing bodies of the state legal entities (or with the state participation). Secondly, in modern conditions the corporate governing bodies of the state assets considered by the state as one of the most important subjects of execution of the state policy in spheres economic, financial, investment, production and other spheres of activity received the special status and development.

Control of state-owned property is exercised by means of activity of state bodies and specially created corporate structures now. The state becomes the active participant of economic processes and provides management of stateowned property. Management of state-owned property allows reaching and using unavailable to the private sector of economy of concentration of the resources necessary for overcoming of negative effects of the universal economic crisis in the Republic of Kazakhstan, decisions in these difficult economic sales terms of large social, ecological, scientific, technical programs.

In relation to this research, we considered corporate management in a broad sense as management in specially created corporate structures - state or with the state participation of legal entities, the purpose of corporate management by state-owned property - implementations of the constitutional principle of economic development for the benefit of all people. During this period, directly there is the forming of structures which purpose of activity shall be the corporate management.

We draw the conclusion on absence at specialized councils for questions of the public corporate management at the Government of the Republic of Kazakhstan of sufficient powers for full administration of the sphere of implementation of the right state-owned property. At the same time, we believe what exactly the lack of administration of the studied sphere is premises of inefficient use of state-owned property, commission of corruption offenses in the field of the public relations.

Multidepartment accessory of the administering functions in the field of activities for management of state-owned property does not promote development of uniform policy, uniform approach to the problem of strategic planning and implementation of the right of state-owned property owing to availability of the different corporate interests pursued by state bodies in the activity.

By results of research shortcomings of the existing system of administration of activities of the companies for management of state assets which are reduced to absence in activity of the central executive bodies, local executive bodies of uniform policy, uniform approach in management of the state share blocks (shares in authorized capital) legal entities with the state participation, owing to different corporate interests are revealed.

Process of forming of the state as effective owner did not find in market conditions the worthy end today. The state looks for new ways and methods of impact on the economic relations answering to creation in the Republic of Kazakhstan of the social, constitutional state in the conditions of new world financial and economic challenges. Implementation of the property right concerning state property allows to create directly necessary and due behavior of the managed subjects. Implementation of the property right integrated to different ways of state and imperious influence brings process of management of state property to qualitatively new level where all interests are subordinated to the state will.

\section{References}

Smith, A. (1993) Research about the nature and the reasons of wealth of the people. M. pp. 119-120.

Blaug, M. Seius and Jean Baptiste (2008) 100 great economists to Keynes = Great Economists before Keynes: An introduction to the lives \& works of one hundred great economists of the past. SPb.: Ekonomikus. pp. 287-289.

Weber, M. (2010) Economy and the society / Lane with it. under scie. edition of L. G. Ionin. M.: Publishing house of GU-VSHE. pp. 456.

Caldwell, B. (2003) Hayek's Challenge: An Intellectual Biography of F. A. Hayek. Chicago and London: University of Chicago Press. pp. 500.

Ebenstein, A. (2003) Hayek's Journey: The Mind of Friedrich Hayek. New York, London/Basingstoke: Palgrave Macmillan. pp. 288.

Friedman, M. \& Friedman R. (2007) Svoboda to choose: our position. M.: New publishing house. pp. 356.

Druker, P. (2012) Management. Challenges XXI century. M.: Eksmo. pp. 256.

Baumol, U. (2013) Microtheory of the innovation entrepreneurship. M.: Publishing house of Institute of Gaidar. pp. 432. 
Kotler, Philip Keller and Kevin Lane (2009): Marketing Management, 13th edition, Upper Saddle River, NJ: Prentice-Hall.

Sachs, Jeffrey D. (2005). The End of Poverty: Economic Possibilities for Our Time. New York: Penguin Books.

Stanley Fisher, Ratna Sahay and Vegh C.A. (2002) Modern Hyper- and High Inflations // NBER Working Paper Series. pp. 8930.

Ioffe, O.S. (1975) Development of civil thought in the USSR. L.: LIE publishing house, 1975. P.1. pp. 160.

Pokrovsky, B.V. (2000) General characteristic of objects of the civil rights//Civil law: The textbook for higher education institutions (the academic course) / the Editor-in-chief: M. K. Suleymenov, Yu.G. Basin. Almaty. T. 1. pp. 228-230.

Shershenevich, G.F. (1995) The textbook of the Russian civil law (according to the edition of 1907). M.: Spark firm. pp. 556.

Doroshenko, E.N. (2005) Constitutional legal regulation of the economic relations. Thesis of the candidate of jurisprudence. M.: RGB. (From RGB funds). pp. 194.

Zhilinsky, E.S. (2005) The constitutional legal basis of differentiation of state-owned property in the Russian Federation. Thesis of the candidate of jurisprudence: M.: RGB (From RGB funds). pp. 181.

Kurilov, A.E. (2003) Economic bases of the constitutional system of the Russian Federation: questions of the theory and practice. Thesis of the candidate of jurisprudence: M.: RGB. (From RGB funds). pp. 215.

Lepyokhin, A.A. (2003) The constitutional legal basis of management of state-owned property in the Russian Federation Thesis of the candidate of jurisprudence: M.: RGB. (From RGB funds). pp. 158.

Mazayev, V.D. (2005) The constitutional bases of public property in the Russian Federation. Thesis of the candidate of jurisprudence: M.: RGB, 2005 (From RGB funds). pp. 356.

Razmyslovich, S. (2003) In Constitutional and legal problems of protection of state-owned property in the Russian Federation. Thesis of the candidate of jurisprudence: M.: RGB (From RGB funds). pp. 164.

Buribayev, E.A. (2014) Some aspects of the constitutional providing relations of management of state-owned property//Messenger of KAZNPU of the name of Abay. No. 3. pp. 28-32.

Basim, YU.G. (2003) To the question of concept of the property right//the Lawyer. No. 8. pp. 14-19.

Suleymenov, M.K. (2008) Gosudarstvo and civil law: problems of the theory and practice//Lawyer. No. 7. pp. 13-23. 